\title{
KESADARAN HUKUM PEKERJA MUSIK KOTA SERANG TERHADAP HAK CIPTA MUSIK DITINJAU DARI UNDANG-UNDANG NO. 28 TAHUN 2014 TENTANG HAK CIPTA
}

\author{
Rohmatullah $^{1}$, Anton Aulawi ${ }^{2}$, Alamsyah Basri ${ }^{3}$ \\ ${ }^{123}$ Universitas Banten Jaya \\ Serang, Indonesia \\ rohmatullah@gmail.com¹, antonaulawi@unbaja.ac.id², alamsyahbasri74@gmail.com³
}

\begin{abstract}
An understanding of copyright is a must-have for every music worker or person in the music industry, because this is closely related to the protection of every work created by musicians so that they are not misused by irresponsible parties and take good profits. financially and existentially. This study aims to determine the awareness of musicians related to Law Number 28 of 2014 Year concerning Copyright and the occurrence of copyright infringement, especially song copyrights in Serang City. The research method used is research with a qualitative approach with data collection techniques, namely observation, interviews and documentation. The results of the study indicate that the influence of the Copyright Law for music workers in Serang City who are members of the Salbai 34 Venue community has not had a significant influence in providing legal protection, because in each of their published musical works, almost on average they have not met to get royalties. per month due to several digital platform rules that put limits on getting royalties from each work that is played and there are still many copyright infringement cases, by unscrupulous music workers, both by musicians and content creators. The level of legal awareness of music workers in Serang City regarding copyright in terms of Law Number 28 of 2014 Year is not yet or still lacks legal awareness. There are four indicators to determine that music workers in Serang City do not yet have good legal awareness, where each of these indicators is a stage for the next stage, namely legal knowledge, legal understanding, legal attitudes, and patterns of understanding community behavior.
\end{abstract}

Keywords: Legal Awareness, Music Workers, Music Copyright

\section{PENDAHULUAN}

Maraknya aplikasi musik digital pada saat ini yang memudahkan para pekerja di bidang musik membuat karya cipta musik dengan menghasilkan nilai ekonomi yang tinggi. Namun dampaknya berimbas pula pada maraknya pelanggaran dan pemalsuan tehadap karya musik digital dilakukan, masalah royalti masih menjadi suatu persoalan dalam industri musik digital di Indonesia, termasuk tantangan baru terhadap peran agregator dan Lemabaga Manajemen Kolektif.

Karya musik atau lagu adalah satu dari banyaknya karya yang telah melekat Hak Cipta serta terdapat hak moral dan hak ekonomi yang jika dilihat dari kacamata hukum telah dilindungi (Darmestha, 2019). Dengan adanya media musik digital seperti Youtube Music, Spotify, Joox, Itunes dan lain sebagainya maka musik telah dapat dinikmati, dikonsumsi, dan dibeli melalui smartphone. (Nanang Kuncoro;2021).

Fenomena yang sekarang marak terjadi pada saat ini adalah menyanyikan ulang (cover) lagu ciptaan orang lain untuk diunggah di media musik digital untuk tujuan komersil tanpa seizin pencipta. Sedangkan pelanggaran terhadap hak cipta yang terjadi selama ini, sering tanpa adanya penyelesaian hukum yang berarti. Salah satu platform musik digital yang paling banyak di kunjungi oleh masyarakat 
adalah sebuah media musik digital berbasis video bernama Youtube. (Nanang Kuncoro:2021).

Situasi pandemi ini kemudian mendorong para musisi untuk semakin bergantung pada aplikasi streaming musik seperti Youtube, Spotify atau Joox. Platform ini membuat distribusi musik menjadi jauh lebih mudah dan menjangkau lebih banyak penikmat musik. Meski begitu, berbeda dengan rilisan fisik, karya musik digital punya risiko pelanggaran hak cipta yang lebih besar. Pada rilisan fisik, pembajakan atau perekaman ulang masih dibatasi kendala teknis seperti penurunan kualitas suara atau resolusi gambar yang tidak sebagus karya orisinil. Pada musik digital, pembajakan dengan kualitas suara dan gambar yang sama dengan karya orisinil jauh lebih mudah dilakukan. Dominasi musik digital juga membawa tantangan baru yaitu penghitungan royalti musik dari platform digital. ( Jesi Andreanto dan Anak Agung Sri Utari, 2014: 12).

Inovasi baru di bidang musik adalah musik digital. Musik Digital adalah musik dengan menggunakan sinyal digital dalam proses reproduksi suaranya. Sebagai proses digitalisasi terhadap format rekaman musik analog, lagu atau musik digital mempunyai beraneka ragam format yang bergantung pada teknologi yang digunakan dengan format MP3, OOG, atau WAV. Banyaknya pemutar musik digital yang mendukung format ini membuat era baru musik digital. Misalnya kalau sebelumnya, musik di ripped istilah untuk ekstraksi audio digital dan terperangkap di PC dan Mac dengan aplikasi semacam itunes. Kini dengan hadirnya iPod sebagai peranti musik portable canggih yang pernah diciptakan, terjadi perpaduan kenyamanan web dengan portabilitas dan fungsi sebagai sebuah platform yang benar-benar universal.(Wikipedia:2021)

Musik digital adalah musik yang diolah secara digital. Musik ini dihasilkan oleh alat musik asli yang direkam secara terpisah pada alat rekaman, alat musik tersebut seperti gitar akustik, piano, bas, drum dan musik alat lainnya, kemudian sampel musik tersebut diolah dan digabungkan secara digital menggunakan peralatan komputer. Jadi musik digital adalah musik yang dihasilkan oleh komputer dengan menggunakan software tertentu misal salah satu software yang sering digunakan adalah Musical Instrument Digital Interface atau biasa disingkat dengan MIDI. (Apriyandis:2011)

Musik digital dibuat untuk mendapatkan suara musik yang lebih jernih dari alat musik sebenarnya. Tentunya dengan berbagai pengolahan yang lebih rumit karena musik digital tidak segampang membuat suara musik sebenarnya. Pada dasarnya kita harus paham tentang ritme dan memahami instrumeninstrumen musik, dan mengerti mengenai proses mixing seluruh instrumen yang digunakan untuk meperoleh suara musik digital yang sempurna tentunya dengan mengagabungkan sampel-sampel musik yang telah kita buat. Adapun contoh musik digital yang kita sering jumpai yaitu dalam bentuk format MP3, WMA, CD Audio dan lainlainnya. Dengan adanya musik digital kita dapat 
memperoleh banyak keuntungan untuk masyarakat dan si pembuatnya.

Hal lain yang mendukung transformasi media sang musik adalah tindakan label-label besar yang meninggalkan sistem proteksi musik digital atau digital right management (DRM). Sampai tahun 2007 lalu, label-label besar masih tidak yakin penghapusan DRM akan mendongkrak penjualan album karena tanpa hal tersebut musik digital dengan bebas didisribusikan di antara konsumen yang berarti tak ada pemasukan untuk label.

Sebagai negara hukum, Indonesia memiliki banyak sekali ketentuan undangundang, salah satu ketentuan undang-undang tersebut adalah undang-undang tentang hak cipta. Berbicara hak cipta, maka sejatinya hak cipta tersebut masuk dalam lingkup hukum Hak Kekayaan Intelektual (HKI). Sebagaimana halnya merek, paten, disain industri dan rahasia dagang. Secara yuridis formal Indonesia diperkenalkan dengan masalah hak cipta pada tahun 1912 yaitu pada saat diundangkannya Auteurswet (Wet van, 23 September 1912, Staatblad 1912 Nomor 600), yang mulai berlaku 23 September 1912 (Rachmadi Usman, 2003: 56)

Undang-Undang Nomor 28 tahun 2014 tentang Hak Cipta (untuk selanjutnya disebut Undang-Undang Hak Cipta) secara umum mengatur tentang pelindungan hak cipta dan penyelesaian sengketa hak cipta.

Dalam Pasal 1 Undang-Undang No.28 Tahun 2014, hak cipta adalah hak eksklusif pencipta yang timbul secara otomatis berdasarkan prinsip deklaratif setelah suatu ciptaan diwujudkan dalam bentuk nyata tanpa mengurangi pembatasan sesuai dengan ketentuan peraturan perundang-undangan. (Apriyandis:2011)

Hak Cipta merupakan salah satu bagian dari kekayaan intelektual yang memiliki ruang lingkup objek dilindungi paling luas, karena mencakup ilmu pengetahuan, seni dan sastra (art and literary) yang di dalamnya mencakup pula program komputer. Perkembangan ekonomi kreatif yang menjadi salah satu andalan Indonesia dan berbagai negara dan berkembang pesatnya teknologi informasi dan komunikasi mengharuskan adanya pembaruan Undang-Undang Hak Cipta, mengingat Hak Cipta menjadi basis terpenting dari ekonomi kreatif nasional. (Sumber, https://www.dgip.go.id/pengenalan-hak-cipta)

Di dalam pasal 58 Undang-Undang Hak Cipta, jangka waktu perlindungan hak cipta secara umum adalah sepanjang hidup penciptanya ditambah 70 tahun untuk karya yang diketahui penciptanya dan karya kolaboratif atau 50 tahun setelah pertama kali diumumkan atau dipublikasikan atau dibuat untuk karya yang dibuat oleh badan hukum, fotografi, dan karya anonim, kecuali 20 tahun setelah pertama kali disiarkan untuk karya siaran (pasal 63 Undang-Undang Hak Cipta),, atau tanpa batas waktu untuk hak moral pencantuman nama pencipta pada ciptaan dan untuk hak cipta yang dipegang oleh Negara atas folklor dan hasil kebudayaan rakyat yang menjadi milik bersama pasal 38 UndangUndang Hak Cipta).

Pemahaman terkait Hak Cipta merupakan hal yang harus dimiliki bagi setiap pekerja 
musik maupun orang yang berkecimpung di industri permusikan, karena hal ini sangat berhubungan erat dengan perlindungan dari setiap karya yang diciptakan oleh musisi agar tidak disalahgunakan oleh pihak-pihak yang tidak bertanggungjawab dan mengambil keuntungan baik secara finansial maupun eksistensi.

Hak Cipta memiliki unsur yang dapat memberikan dampak ekonomi bagi seorang pemilik karya, maka dalam hal ini pemahaman terkait perlindungan hak cipta sudah seharusnya dimiliki oleh pekerja musik tersebut baik bagi musisi, pencipta lagu, pemain pertunjukan, serta orang-orang yang berkecimpung di industri permusikan agar tidak ada pihak-pihak yang dirugikan baik secara finansial maupun moral.

Dengan adanya Undang-Undang Hak Cipta tersebut para pekerja musik (musisi, pencipta lagu dll) tidak ragu lagi mengekspos karyanya untuk dapat dinikmati khalayak umum dan dapat pula menjadi mata pencaharian demi menghidupi kebutuhan sehari-harinya. Dalam mencapai kesejahteraan tentunya sangat dipengaruhi oleh banyak hal salah satunya para pekerja musik khususnya pencipta lagu harus mendaftarkan karyanya melalui Asosiasi Hak Cipta yang telah terafiliasi oleh Kementrian Hukum dan Hak Asasi Manusia agar memiliki kekuatan hukum jika suatu saat ada pihak yang mengklaim demi mendapatkan keuntungan secara finansial ataupun keuntungan secara ekonomi.

Berdasarkan penelitian yang Peneliti lakukan kepada komunitas pekerja musik yang tergabung di komunitas Salbai 34 Venue di
Kota Serang. Salbai 34 Venue merupakan tempat berkumpulnya musisi yang berlokasi di Kota Serang yang biasanya dijadikan tempat untuk berdiskusi maupun sharing terkait hal-hal yang sedang menjadi tren di dunia hiburan. Dalam hasil wawancara dengan beberapa informan diperoleh kesimpulan bahwa pekerja musik di Kota Serang belum memahami secara jelas terkait Undang-Undang Hak Cipta, bagaimana proses untuk mendaftarkan karya yang telah diciptakanya dalam hal ini yaitu musik dan apa tujuan dari hak cipta yang sebenarnya, yang bagi Pekerja Musik ketahui, baru sebatas bahwa hak cipta bertujuan untuk melindungi karya yang telah dibuatnya dan untuk seterusnya masih belum paham bagaimana cara mendaftarkan hak ciptanya tersebut. Kesimpulannya adalah bahwa Pekerja Musik sudah tahu tentang adanya undangundang hak cipta, akan tetapi untuk memahami isi dari undang-undang tersebut mereka cukup kesulitan memahaminya karena pengetahuannya tentang hukum terbatas dan bahasa dari undang-undang masih terlalu sulit untuk dipahami mereka.

Selain masalah pemahaman undangundang Hak Cipta beberapa informan juga memberi keterangan bahwa ada karya mereka yang dikomersilkan orang lain tanpa izin dari mereka, karya mereka dalam bentuk digital tersebut diambil dan dikomersilkan melalui beberapa situs web atau media internet tanpa seijin dari Penciptanya yaitu mereka. Maka sebenarnya mereka sebagai pencipta/pemilik lagu berhak untuk menuntut. Namun disini mereka belum mengerti bagaimana cara untuk menuntut pihak lain yang mengkomersilkan 
lagu tersebut tanpa ijin, dan bagaimana cara mendaftarkan lagu tersebut agar memiliki kekuatan hukum yang sah (legalitas).

Peneliti melakukan penelitian pada Pekerja Musik di Kota Serang yang tergabung dalam komunitas Salbai 34 Venue, karena Peneliti ingin tahu seberapa paham pengetahuan hukum dan kesadaran hukum para pekerja musik di Kota Serang khususnya tentang Undang-Undang Hak Cipta, sehingga dapat mengantisipasi pelanggaran tentang hak cipta lagu/musik.

Yang melatarbelakangi mengapa Peneliti melakukan penelitian di Salbai 34 Venue, karena penulis ingin tahu kesadaran hukum Pekerja Musik yang berada di lingkungan Kota Serang tentang Undang-Undang Hak Cipta. Untuk itu Peneliti ingin mengetahui lebih jauh mengenai kesadaran hukum tentang hak cipta dan bagaimana mendaftarkan hak cipta serta dalam meningkatkan kesejahteraan Pekerja Musik di Kota Serang.

Kesadaran hukum secara sederhana yaitu tanggapan seketika, pengalaman langsung yang dapat berupa kesan, perasaan dan keinginan dari seseorang terhadap hukum.

Menurut Soerjono Soekanto terdapat empat indikator kesadaran hukum yang masing merupakan suatu tahapan bagi tahapan berikutnya, yaitu pengetahuan hukum, pemahaman hukum, sikap hukum, dan pola pemahaman perilaku masyarakat. (Saifullah 2007:105)

Berdasarkan latar belakang masalah tersebut, maka penelitian ini difokuskan pada, "Kesadaran Hukum Pekerja Musik Kota Serang Terhadap Hak Cipta Musik Ditinjau Dari
Undang-Undang No. 28 Tahun 2014 Tentang Hak Cipta”.

\section{METODE PENELITIAN}

Penelitian ini dilakukan pada Komunitas Musisi di lingkungan Salbai 34 Venue, yang berlokasi di Jl. Saleh Baimin No.34, serta beberapa musisi yang berada di Kota Serang.

Pendekatan yang digunakan dalam penelitian ini adalah pendekatan kualitatif yaitu prosedur penelitian yang menggambarkan suatu keadaan dan gejala yang ada pada objek yang akan diteliti. Penelitian kualitatif lebih diarahkan untuk memahami fenomenafenomena sosial dari perspektif partisipan. Ini diperoleh melalui pengamatan partisipatif dalam kehidupan orang-orang yang menjadi partisipan. (Sudaryono, 75:2018)

Adapun teknik pengumpulan data yang akan dilakukan peneliti pada penelitian ini adalah sebagai berikut:
a) Pengamatan (Observation)
b) Wawancara
c) Dokumentasi

Dalam pengecekan data peneliti menggunakan teknik pemeriksaan keabsahan data yaitu triangulasi. Peneliti menggunakan teknik ini untuk menghilangkan perbedaanperbedaan konstruksi kenyataan yang ada dalam konteks suatu studi sewaktu mengumpulkan data tentang berbagai kejadian dan hubungan dari berbagai pandangan.

Langkah yang digunakan dalam teknik triangulasi data ini adalah dengan menggunakan sumber dan metode.

Dengan cara ini penelitian dapat menarik kesimpulan yang mantap tidak hanya dari satu 
cara pandang sehingga bisa diterima kebenarannya. Penerapannya, peneliti membandingkan data hasil pengamatan dengan hasil wawancara serta dokumentasi yang berkaitan. Dengan demikian, apa yang diperoleh dari sumber yang satu bisa lebih teruji kebenarannya, bilamana dibandingkan data sejenis yang diperoleh dari sumber lain yang berbeda.

Analsis data dalam penelitian ini dilakukan melalui tiga kegiatan yang terjadi secara bersamaan yaitu redaksi data, penyajian data, dan penarikan kesimpulan atau verifikasi (Sugiyono, 2016:334). Analisis data kualitatif merupakan upaya yang berlanjut, berulang dan menerus. Masalah reduksi data, penyajian data, dan penarikan kesimpulan merupakan rangkaian kegiatan analisis yang saling menyusul.

Berdasarkan langkah-langkah tersebut, maka dalam penelitian ini pada tahap awal setelah diadakan pengumpulan data melalui teknik wawancara dengan berbagai sumber data yang dianggap mengetahui tentang Kesadaran Hukum Pekerja Musik di Kota Serang ditinjau dari UU No. 28 Tahun 2014 tentang Hak Cipta di lingkungan Salbai 34 Venue, yang berlokasi di Jl. Saleh Baimin No.34, Kelurahan Cipare, Kecamatan Serang, Kota Serang-Banten. Selain itu dikumpulkan pula hasil observasi dan dokumentasi yang diperoleh sesuai dengan rumusan masalah dalam penelitian ini.

Data-data telah terkumpul dan dipilahpilah sesuai dengan permasalahan yang diteliti, kemudian disajikan dalam bentuk naratif atau dideskriptifkan secara gamblang yang sebenarnya yang ditemui dari hasil penelitian penyajian data tersebut disajikan.

\section{PEMBAHASAN}

Pengaruh Undang-Undang No. 28 Tahun 2014 Tentang Hak Cipta terhadap Perlindungan Hukum Terhadap Hak Cipta Musik Pekerja Musik di Komunitas Salbai 34 Venue Kota Serang

Undang-Undang Nomor 28 tahun 2014 tentang Hak Cipta secara umum mengatur tentang:

1) Pelindungan Hak Cipta dilakukan dengan waktu lebih panjang sejalan dengan penerapan aturan di berbagai negara sehingga jangka waktu pelindungan Hak Cipta di bidang tertentu diberlakukan selama hidup pencipta ditambah 70 (tujuh puluh) tahun setelah Pencipta meninggal dunia.

2) Perlindungan yang lebih baik terhadap hak ekonomi para Pencipta dan/atau Pemilik Hak Terkait, termasuk membatasi pengalihan hak ekonomi dalam bentuk jual putus (sold flat).

3) Penyelesaian sengketa secara efektif melalui proses mediasi, arbitrase atau pengadilan, serta penerapan delik aduan untuk tuntutan pidana.

4) Pengelola tempat perdagangan bertanggung jawab atas tempat penjualan dan/atau pelanggaran Hak Cipta dan/atau Hak Terkait di pusat tempat perbelanjaan yang dikelolanya.

5) Hak Cipta sebagai benda bergerak tidak berwujud dapat dijadikan objek jaminan fidusia. 
6) Menteri diberi kewenangan untuk menghapus Ciptaan yang sudah dicatatkan, apabila Ciptaan tersebut melanggar norma agama, norma susila, ketertiban umum, pertahanan dan keamanan negara, serta ketentuan peraturan perundang-undangan.

7) Pencipta, Pemegang Hak Cipta, pemilik Hak Terkait menjadi anggota Lembaga Manajemen Kolektif agar dapat menarik imbalan atau Royalti.

8) Pencipta dan/atau pemilik Hak Terkait mendapat imbalan Royalti untuk Ciptaan atau produk Hak Terkait yang dibuat dalam hubungan dinas dan digunakan secara komersial.

9) Lembaga Manajemen Kolektif yang berfungsi menghimpun dan mengelola hak ekonomi Pencipta dan pemilik Hak Terkait wajib mengajukan permohonan izin operasional kepada Menteri.

10) Penggunaan Hak Cipta dan Hak Terkait dalam sarana multimedia untuk merespon perkembangan teknologi.

Pengaruh Undang-Undang Hak Cipta untuk pekerja musik di Kota Serang yang tergabung dalam komunitas Salbai 34 Venue belum mempunyai pengaruh yang signifikan dalam memberi perlindungan hukum, dikarenakan pada setiap karya musik mereka yang dipublish hampir rata-rata belum memenuhi untuk mendapatkan royalti perbulan karena beberapa aturan platfrom digital yang menaruh batasan untuk mendapatkan royalti dari setiap karya yang diperdengarkan. Bukan tanpa tujuan platfrom tersebut menaruh aturan seperti itu, karena pada umumnya bagi Pekerja Musik yang benar-benar ingin mendapat bayaran dari setiap karya yang diperdengarkan orang lain. Kinerja pekerja musik (musisi atau grup band) dinilai oleh perusahaan/label tersebut dilihat dari seberapa seriuskah dalam mempromosikan karyanya tersebut sehingga menarik orang untuk mendengarkan melalui platfrom tersebut sehingga pemasukan iklan lebih banyak masuk dan dari situlah Pekerja Musik mendapatkan bayarannya melalui iklan tersebut.

Pengaruh positifnya dari Undang-Undang Hak Cipta untuk pekerja musik di Kota Serang yang tergabung dalam komunitas Salbai 34 Venue antara lain pada era digitalisasi sekarang ini cukup mempermudah para musisi untuk dapat menyebarkan karyanya melalui platfromplatfrom digital berbayar yang dimana karya tersebut dapat menghasilkan royalti nantinya. Untuk menyebarkan karyanya ke khalayak umum, langkah pertama yang ditempuh oleh seorang pekerja musik adalah mendaftarkan karyanya melalui publisher yang nantinya dari publisher tersebut akan disalurkan ke media musik atau platfrom-platfrom penyedia layanan musik berbayar.

Dalam hal ini kasus ini sedang marak di era digital sekarang dimana pengguna musik Sportiy merupakan situs internet yang menyediakan berbagai macam konten musik. Saat ini banyak pengguna streaming dalam mengunggah video menggunakan suara latar lagu dengan tidak mencantumkan sumber lagu tersebut. Untuk mengetahui perlindungan hak cipta terhadap penggunaan lagu sebagai suara latar dalam video di situs Youtube berdasarkan UUHC serta upaya hukum yang dapat dilakukan atas pelanggaran terhadap 
penggunaan lagu sebagai suara latar di dalam video. (Nevey Varida Ariani; 2021).

Perlindungan karya cipta khususnya musik di dalam penggunaannya sebagai suara latar dalam video yang diunggah di situs Youtube diatur dalam Pasal 5 dan Pasal 9 UU Hak Cipta. Selain UU Hak Cipta, Youtube juga memberikan perlindungan hukum hak cipta dengan pemberian lisensi dan melalui lisensi tersebut pemegang hak cipta dapat melakukan klaim content id apabila terjadi pelanggaran dalam penggunaan materi yang dilindungi oleh hak cipta. Pencipta dapat melakukan upaya hukum preventif dan upaya represif dalam hal terjadi pelanggaran terhadap ciptaannya. (Desak Komang Lina Maharani:2019).

Jika diibaratkan karya adalah anak yang harus kita jaga dan kita besarkan, sedangkan bagaimana agar karya kita dapat diakui oleh Negara, maka salah satunya adalah kita harus mendaftarkannya melalui aggregator musik yang ada di negara ini, dan setelah didaftarkan barulah kita memiliki hak atas karya tersebut.

Seperti itu pengaruh Undang-Undang Hak Cipta untuk pekerja musik yang berada di Kota Serang dan Salbai 34 Venue khususnya.

Adanya perlindungan hukum seperti itu dimaksudkan agar pemilik hak dapat menggunakan atau mengeksploitasi kekayaan intelektualnya dalam bidang musik dengan aman. Pada gilirannya, rasa aman itulah yang kemudian menciptakan iklim atau suasana yang memungkinkan orang dapat terus berkarya guna menghasilkan ciptaan atau temuan berikutnya. Sebaliknya, dengan perlindungan hukum pula, pemilik diminta untuk mengungkap jenis, bentuk, dan cara kerja serta manfaat dari kekayaan itu. Pekerja musik tersebut dapat aman mengungkapkan (discloses) karena adanya jaminan perlindungan hukum, sebaliknya masyarakat dapat ikut menikmati atau menggunakan atas dasar izin atau bahkan mengembangkannya secara lebih lanjut. Dalam hal ini hukum bukan hanya berfungsi mendisiplinkan ekonomi, tetapi terwujud dalam kegiatan-kegiatan ekonomi itu sendiri. Ini berarti bahwa kehadiran sistem peraturan (hukum) merupakan syarat mutlak untuk dapat berlangsungnya kegiatan ekonomi atau bisnis.

Sebagian besar pekerja musik di Kota Serang yang tergabung dalam komunitas Salbai 34 Venue belum pernah membaca undangundang tersebut secara keseluruhan. Menurut mereka, untuk urusan seperti legalitas atau aturan-aturan yang harus dipatuhi oleh pekerja musik itu sudah ada bagian yang mengurusi dan harus orang yang berkompeten di bidang tersebut. Karena pekerja musik disini bertugas untuk membuat sebuah karya yang bagus. Jika sebatas mengetahui undang-undang Hak Cipta itu ada pasti hampir semua pekerja musik tahu itu. Karena pekerja musik yang sudah benarbenar fokus di industri permusikan pasti akan menghindari pelanggaran yang akan terjadi tapi hanya beberapa aturan saja yang diketahui.

Hampir setiap pekerja musik membutuhkan wadah yang dapat menampung serta mensuplai karyanya hingga ke telinga si pendengar. Mungkin ini adalah salah satu keuntungan yang ditawarkan oleh pihak-pihak yang memiliki kewenangan untuk mengatur kekayaan intelektual di era digital ini. Maka dari itu mereka berpendapat bahwasanya pada pelaksanaannya diharapkan pihak-pihak terkait 
dapat memikirkan nasib para pekerja musik kecil yang masih merintis karir dan benar-benar ingin hidup dalam dunia hiburan dan juga semoga pemerintah dapat mensosialisasikannya terhadap para pekerja musik lokal.

Sebagian besar pekerja musik di Kota Serang yang tergabung dalam komunitas Salbai 34 Venue ini mengungkapkan bahwa undangundang tentang hak cipta memang sudah cukup lama akan tetapi untuk undang-undang tentang permusikan dapat dibilang baru. Menurut mereka untuk mengetahui secara detail isi dari undang-undang tersebut sepertinya untuk sebagian besar pekerja musik di Kota Serang yang tergabung dalam komunitas Salbai 34 Venue belum cukup untuk bisa dipahami dan Pemerintah belum cukup sosialisasi kepada pekerja musik kecil apalagi pekerja musik yang masih berkarya di wilayah Kota Serang yang notabene-nya belum cukup orang-orang yang dapat memotivasi mereka ke hal-hal yang bersangkutan dengan hukum. Sedikit pengalaman dari mereka, jika pekerja musik ingin benar-benar menikmati hasil dari karya mereka secara finansial seharusnya pekerja musik paham bagaimana cast flow nya industri permusikan yang ada di tanah air. Mulai dari hulu ke hilir nya sebuah karya yang dilahirkan oleh pekerja musik. Jika diibaratkan karya adalah anak yang harus kita jaga dan kita besarkan, sedangkan bagaimana agar karya kita dapat diakui oleh Negara, salah satunya adalah kita harus mendaftarkannya melalui aggregator musik yang ada di negara ini. Dan setelah didaftarkan barulah kita memiliki hak atas karya tersebut.
Kesadaran Hukum Pekerja Musik di Komunitas Salbai 34 Venue Kota Serang Tentang Hak Cipta Ditinjau Dari UndangUndang No. 28 Tahun 2014

Kesadaran hukum secara sederhana yaitu tanggapan seketika, pengalaman langsung yang dapat berupa kesan, perasaan dan keinginan dari seseorang terhadap hukum. Selain pengertian tersebut, kesadaran hukum dapat dipahami sebagai berikut:

Pertama, kesadaran hukum yang berarti bahwa hukum itu merupakan kaidah yang fungsinya untuk melindungi kepentingan orang. Kepentingan tiap orang berbeda. Seperti halnya kepentinganmu dengan kepentingan temanmu tentu berbeda. (Sri Kartini, 2020:07)

Kedua, kesadaran tentang kewajiban hukum kita terhadap orang lain. Di sini, ketika menuntut hak akan hukum kamu dibatasi oleh hak orang lain terhadap hukum itu. Dengan kata lain, seseorang akan melakukan apa yang seharusnya dilakukan atau tidak dilakukan terhadap hukum. (Sri Kartini, 2020:08)

Menurut Soerjono Soekanto terdapat empat indikator kesadaran hukum yang masing merupakan suatu tahapan bagi tahapan berikutnya, yaitu pengetahuan hukum, pemahaman hukum, sikap hukum, dan pola pemahaman perilaku masyarakat. (Saifullah 2007:105)

\section{Pengetahuan Hukum}

Pengetahuan hukum adalah pengetahuan seseorang mengenai beberapa perilaku tertentu yang diatur oleh hukum. sudah tentu bahasa hukum yang dimaksud disini adalah hukum tertulis dan hukum tidak tertulis. Pengetahuan tersebut berkaitang dengan prilaku yang 
dilarang ataupun prilaku yang diperbolehkan oleh hukum. Sebagaimana dapat dilihat di dalam masyarakat bahwa pada umumnya seseorang mengetahui bahwa membunuh, mencuri, dan seterusnya dilarang oleh hukum.

Melihat indikator ini, maka pengetahuan hukum Pekerja Musik di kota Serang masih kurang karena faktor kurangnya pendidikan mereka khususnya di bidang hukum. Kurangnya tingkat pendidikan hukum Pekerja Musik di kota Serang disebabkan oleh faktor ekonomi.

Fakor ekonomi merupakan faktor terbesar penyebab terjadinya masalah sosial termasuk kepada pendidikan formal. tindakan kriminal dan pelanggaran hukum. Masalah tersebut didorong adanya ketidakmampuan seseorang dalam memenuhi kebutuhan hidupnya secara layak, misalnya pengangguran dan kemiskinan. Faktor ekonomi juga dapat dijadikan sebagai acuan maju atau tidaknya suatu negara, serta faktor ekonomi dapat memengaruhi masalah pengetahuan dan kesadaran hokum masyarakat termasuk juga pekerja musik di Kota Serang.

\section{Pemahaman Hukum}

Pemahaman hukum dalam arti disini adalah sejumlah informasiyang dimiliki seseorang mengenai isi peraturan dari hukum tertentu. Dengan lain perkataan pemahaman hukum adalah suatu pengertian terhadap isi dan tujuan dari suatu peratuan dalam suatu hukum tertentu, tertulis maupun tidak tertulis, serta manfaatnya bagi pihak-pihak yang kehidupannya tidak disyaratkan seseorang harus terlebih dahulu mengetahui adanya suatu aturan tertulis yang mengatur sesuatu hal, akan tetapi yang dilihat disini adalah bagaimanapersepsi mereka dalam mengahadapi berbagai hal, dalam kaitannya dengan norma-norman yang ada dalam masyarakat.

Melihat indikator ini, maka pemahaman hukum Pekerja Musik di kota Serang masih kurang karena faktor kurangnya sosialisasi tentang UU No. 28 Tahun 2014 oleh instansi terkait kepada masyarakat, khususnya pekerja musik. Bagi Pekerja Musik isi Undang-Undang Hak Cipta masih terlalu sulit untuk dipahami mereka yang awam hukum. Sosialisasi hukum pun menjadi faktor yang sangat penting untuk membangun kesadaran hukum bagi Pekerja Musik di kota Serang supaya mereka lebih sadar dan paham terhadap hukum.

3. Sikap Hukum

Sikap hukum adalah suatu kecendrungan untuk menerima hukum karena adanya penghargaan terhadap hukum sebagai sesuatu yang bermanfaat atau menguntungkan jika hukum itu ditaati. Sebagaimana terlihat di sini bahwa kesadaran hukum berkaitan dengan nilai-nilai yang terdapat dimasyrakat. Suatu sikap hukum akan melibatkan pilihan warga terhadap yang sesuai dengan nilai-nilai yang ada dalam dirinya sehingga akhirnya warga masyarakat menerima hukum berdasarkan penghargaan terhadapnya.

Melihat indikator ini, maka sikap hukum Pekerja Musik di kota Serang masih kurang faktor sikap moral atau karakter merupakan faktor yang dapat mempengaruhi terjadinya penyalahgunaan karya untuk dijadikan ladang uang melalui platform digital yang menyediakan iklan berbayar. Kurangnya sikap moral atau karakter merupakan salah faktor 
yang disebabkan oleh faktor ekonomi yang menyebabkan Pekerja Musik dengan mudahnya tergoda untuk melakukan plagiasi atau menjual karya orang lain melalui platform digital yang menyediakan iklan berbayar tanpa seizin pemiliknya. Faktor kurangnya sikap moral yang sering terjadi dimana pemilik karya kurang terkenal dibanding musisi yang mengcover karyanya. Dengan terbentuknya kesadaran hukum ini diharapkan dapat meminimalisir terbentuknya mafia-mafia di industri kreatif khususnya di permusikan.

\section{Pola Perilaku Pemahaman Masyarakat}

Perilaku hukum, Pola perilaku hukum merupakan hal utama dalam kesadaran hukum karena disini dapat dilihat apakah suatu peraturan berlaku atau tidak dalam masyarakat. Dengan demikian sampai seberapa jauh kesadaran hukum dalam masyarakat dapat dilihat dari pola prilaku hukum suatu masyarakat.

Melihat indikator ini, maka pola perilaku pemahaman masyarakat khususnya Pekerja Musik di kota Serang terhadap hukum atau untuk mematuhi hukum masih kurang.

Faktor tersebut bisa disebabkan adanya faktor tradisi dan kebiasaan yang dilakukan secara terus menerus sehingga lupa akan karya orang lain yang terus di cover oleh musisi tersebut.

Pelanggaran hak cipta dapat berupa perbuatan mengambil, merekam, memperbanyak dan mengumumkan ciptaan orang lain, baik sebagian maupun seluruhnya tanpa izin pencipta atau pemegang hak cipta, yang bertentangan dengan Undang-undang Hak
Cipta, artinya tidak sesuai atau melanggar ketentuan Undang-undang Hak Cipta.

Kejahatan pelanggaran Hak Cipta pada HKI katanya dapat dibedakan atas dua yaitu:

1) Mengambil atau mengutip sebagian ciptaan orang lain dan dimasukkan ke dalam ciptaan sendiri seolah-olah itu ciptaan sendri atau mengakui ciptaan orang lain seolah-olah ciptaan sendiri. Perbuatan ini disebut plagiat. Hal ini dapat terjadi pada lagu, lirik lagu dan notasi lagu.

2) Mengambil ciptaan orang lain untuk diperbanyak dan diumumkan sebagaimana aslinya tanpa mengubah bentuk, pencipta atau pengarang, penerbit atau perekam. Perbuatan ini disebut Pembajakan. Pembajakan banyak dilakukan pada karya tulis berupa buku dan karya rekaman audio dan video seperti kaset lagu dan kaset video atau Compact Disc (CD)

Pada kasus di atas cukup sering ditemui para pekerja musik baik ada yang melanggar sebagai pelaku maupun yang menjadi korban karyanya dibajak orang lain.

Hal seperti itu cukup sering ditemukan pada pekerja musik di Kota Serang yang pernah melakukan pelanggaran hak cipta musik ketika mereka membuat sebuah konten dan memakai backsong dari lagu milik orang lain dan meng upload konten tersebut ke media sosialnya. Para pekerja musik menyadari bahwa mereka telah melanggar aturan hak cipta akan tetapi menurut pasal yang mana mereka sendiri tidak tahu karena pemberitahuan yang masuk ke pekerja musik di Kota Serang tidak menjelaskan secara spesifik pasal yang telah dilanggarnya. 
Pada kasus yang terjadi kepada pekerja musik di Kota Serang memang sering di temukan baik bagi pencipta lagu atau content creator karena mereka hanya memikirkan bagaimana terus membuat konten yang bagus dan disukai banyak orang tapi tidak memikirkan bagaimana aturan yang berlaku. Akan tetapi hal ini bukanlah kasus besar yang harus menempuh jalur hukum untuk menyelesaikannya karena kasus ini dapat diselesaikan dengan kesadaran dari masingmasing orang yang melanggarnya. Tidak seperti kasus yang pernah dialami oleh salah satu pekerja musik di Kota Serang bernama Aldo yang mengalami kerugian besar secara materi/finansial karena hak ciptanya dimiliki oleh orang lain dan royalti yang masuk tidak kepada Aldo melainkan orang lain. Kasus itu terjadi ketika produk Ring Back Tone masih kencang-kencangnya beredar di masyarakat dan masih memiliki market pasar yang besar.

Berdasarkan Pasal 1 ayat (2) UUHC terkait dengan royalti adalah imbalan atas pemanfaatan hak ekonomi suatu ciptaan atau produk hak terkait yang diterima oleh pencipta atau pemilik Hak terkait. Pembayaran yang diberikan oleh pengguna hak cipta atau produk terkait kepada pencipta dan atau pemegang hak terkait sehubungan dengan pemberian izin utnuk mengeksploitasi atau menggunakan ciptaan atau produk hak terkait. Biasanya dalam jumlah pembayaran suatu royalti dilakukan berdasarkan kesepakatan dengan ukuran-ukuran tertentu yang kemudian diatuangkan dalam bentuk penjanjian tertulis atau akta. Pencipta atau Pemegang Hak Cipta memiliki keterbatasan untuk menjadikan ciptaanya menjadi uang. Dalam hal ini pencipta membutuhkan peran pihak lain untuk mengalihkan semua atau sebagian hak ekonominya pada pihak lain dalam bentuk lisensi. Sebuah karya seni pencipta dapat memberikan lisensi kepada sebuah label musik untuk mempromosikan lagu atau musik ciptaanya agar dikenal oleh masyarakat dan memiliki nialai ekonomi yang tinggi dari pemutaran streaming musik tersebut. (Nevey Varida Ariani; 2021).

Jika pada era sebelum berkembangnya digitalisasi kasus seperti pembajakan memang cukup marak terjadi dan dalam hal ini banyak pihak-pihak yang dirugikan baik dari label rekaman maupun dari pihak musisinya. Akan tetapi kasus seperti itu turun drastis ketika era digitalisasi masuk dan mulai merubah pasar industri permusikan yang tadinya menjual melalui fisik dan sekarang menjualnya melalui digital dimana diharuskan untuk merubah strategi pemasaran maupun secara legalitas untuk melindungi hak ciptanya.

Royalti merupakan pembayaran sebagai bentuk penghargaan atas penggunaan hasil karya cipta musik dan lagu yang dipergunakan untuk keperluan komersial. Undang-Undang Hak Cipta memang tidak memberikan defenisi mengenai royalti, namun Pasal 80 Undangundang Hak Cipta menyebutkan bahwa:

1) Kecuali diperjanjikan lain, pemegang Hak Cipta atau pemilik Hak Terkait berhak memberikan Lisensi kepada pihak lain berdasarkan perjanjian tertulis untuk me.laksanakan perbuatan sebagaimana dimaksud dalam Pasal 9 ayat (1), Pasal 23 
ayat (21, Pasal 24 ayat (2), dan Pasal 25 ayat (2).

2) Perjanjian Lisensi sebagaimana dimaksud pada ayat (1) berlaku selama jangka waktu tertentu dan tidak melebihi masa berlaku Hak Cipta dan Hak Terkait.

3) Kecuali diperjanjikan lain, pelaksanaan perbuatan sebagaimana dimaksud pada ayat (1) disertai kewajiban penerima Lisensi untuk memberikan Royalti kepada Pemegang Hak Cipta atau pemilik Hak Terkait selama jangka waktu Lisensi.

4) Penentuan besaran Royalti sebagaimana dimaksud pada ayat (3) dan tata cara pemberian Royalti dilakukan berdasarkan perjanjian Lisensi antara Pemegang Hak Cipta atau pemilik Hak Terkait dan penerima Lisensi.

5) Besaran Royalti dalam perjanjian Lisensi harus ditetapkan berdasarkan kelaziman praktik yang berlaku dan memenuhi unsur keadilan.

Pembayaran royalti merupakan bagian konsekuensi dari menggunakan jasa/karya orang lain, sebab dalam kehidupan sehari-hari, lagu merupakan salah satu sarana penunjang dalam kegiatan usaha atau komersial. Alasan inilah yang mendasari kewajiban publisher membayar royalti, sebab lagu adalah suatu karya intelektmempegaruhiual manusia yang mendapat perlindungan hukum dan untuk itu jika pihak lain menggunakannya sudah sepatutnya meminta izin kepada pemilik atau pemegang hak cipta.

Jumlah penerimaan royalti sebuah lagu setiap tahunnya akan berbedabeda, karena bisa saja di tahun ini lagu itu terkenal dan didengarkan dimana-mana, tetapi tahun berikutnya lagu itu hampir tidak diperdengarkan lagi.

Harus diakui bahwa kebiasaan pada masyarakat yang menganggap persoalan hukum sebagai yang tidak perlu dibesar-besarkan merupakan salah satu kendala yang terbesar dalam melaksanakan perlindungan hukum. Hal ini disebabkan kondisi sebagian dari masyarakat yang bersikap skeptis atau mengabaikan terhadap hukum, masyarakat selalu menghendaki sesuatu sesederhana mungkin walaupun kemudian mengabaikan rasa kepatuhan terhadap hukum. Kondisi seperti ini tidak hanya dalam bidang hak cipta, akan tetapi hampir dalam setiap bidang yang melibatkan masyarakat sebagai obyek. Akar permasalahan dari budaya masyarakat seperti itu sangatlah ditentukan oleh pengetahuan dan kepatuhan masyarakat itu sendiri terhadap suatu aturan hukum yang dalam istilah sosiologisnya bahwa kepatuhan atau kesadaran ataukah ketaatan hukum warga masyarakat terhadap suatu aturan sangat ditentukan oleh nilai-nilai intrinsik yang dianut oleh masyarakat itu.

Kesadaran dan ketaatan hukum masyarakat khususnya pekerja musik sangat mempengaruhi terjadinya pelanggaran hak cipta lagu di Kota Serang. Karena sesungguhnya pekerja musik menyadari bahwa hal itu melanggar hak cipta orang lain namun mereka tetap saja tidak taat hukum. Dalam hal ini, pekerja musik di Kota Serang memiliki kesadaran hukum dan ketaatan hukum yang kurang baik.

Dilihat dari kesadaran hukum pekerja musik di Kota Serang, maka yang 
mempengaruhinya adalah, faktor ekonomi, faktor tradisi atau kebiasaan, faktor Pendidikan dan faktor moral merupakan faktor yang dapat mempengaruhi terjadinya penyalahgunaan hak cipta orang lain untuk diambil keuntungan sendiri secara ilegal melalui platform digital yang menyediakan iklan berbayar. Pendidikan yang rendah merupakan salah satu faktor yang disebabkan oleh kemampuan ekonomi yang kurang dan menyebabkan oknum pekerja musik dengan tanpa hak menjual atau mengkomersilkan hasil karya orang lain melalui platform digital yang menyediakan iklan berbayar tanpa seizin pemiliknya. Adapula yang disebabkan adanya faktor tradisi dan kebiasaan yang dilakukan secara terus menerus sehingga lupa akan karya orang lain yang terus dicover oleh oknum tersebut. Faktor moral juga salah satu penyebab sering terjadinya cover lagu illegal dari pencipta lagu yang kurang terkenal yang lagunya dicover oleh Penyanyi yang lebih terkenal. Dengan terbentuknya kesadaran hukum ini diharapkan dapat meminimalisir terbentuknya mafia-mafia di industri kreatif khususnya di permusikan.

Solusi yang ingin dicapai dalam penelitian ini adalah terbentuknya kesadaran hukum bagi pekerja musik di Kota Serang mengenai aturan hukum atau regulasi terkait Hak Cipta khususnya di industri permusikan agar tidak adalagi pekerja musik yang takut akan karyanya disalahgunakan oleh oknum orang-orang yang tidak bertanggung jawab dengan mengambil keuntungan dari karya music ciptaan mereka secara ilegal.

\section{KESIMPULAN}

1. Pengaruh Undang-Undang No. 28 Tahun 2014 tentang Hak Cipta terhadap perlindungan hukum terhadap hak pekerja musik di Kota Serang, adalah belum efektif atau berimbas positif. Hal ini terlihat masih banyaknya terjadi pelanggaran hak cipta, oleh oknum pekerja musik baik oleh musisi maupun content creator. Pengaruh Undang-Undang Hak Cipta untuk pekerja musik di Kota Serang yang tergabung dalam komunitas Salbai 34 Venue belum mempunyai pengaruh yang signifikan dalam memberi perlindungan hukum, dikarenakan pada setiap karya musik mereka yang dipublish hampir ratarata belum memenuhi untuk mendapatkan royalti perbulan karena beberapa aturan platfrom digital yang menaruh batasan untuk mendapatkan royalti dari setiap karya yang diperdengarkan. Sedangkan sedikit pengaruh positifnya dari UndangUndang Hak Cipta untuk pekerja musik di Kota Serang yang tergabung dalam komunitas Salbai 34 Venue antara lain pada era digitalisasi sekarang ini cukup mempermudah para musisi untuk dapat menyebarkan karyanya melalui platfromplatfrom digital berbayar yang dimana karya tersebut dapat menghasilkan royalti nantinya.

2. Tingkat kesadaran hukum pekerja musik di Kota Serang tentang hak cipta ditinjau dari Undang-Undang No. 28 Tahun 2014 adalah belum atau masih kurang kesadaran hukumnya. Kesadaran hukum pekerja musik sangat mempengaruhi terjadinya 
pelanggaran hak cipta lagu di Kota Serang.

Karena sesungguhnya pekerja musik menyadari bahwa hal itu melanggar hak cipta orang lain. Dalam hal ini, pekerja musik di Kota Serang cukup apatis dalam kesadaran hukum walaupun aturan tersebut sangat berpengaruh untuk dirinya dalam berkarir di industri permusikan. Akan tetapi tak jarang pula dari pekerja musik di Kota Serang yang masih awam akan hukum. Ada empat indikator untuk mengetahui bahwa pekerja musik di Kota Serang belum memiliki kesadaran hukum yang baik, dimana masing-masing indikator tersebut merupakan suatu tahapan bagi tahapan berikutnya, yaitu pengetahuan hukum, pemahaman hukum, sikap hukum, dan pola pemahaman perilaku masyarakat. Dilihat dari kesadaran hukum pekerja musik di Kota Serang, maka yang mempengaruhinya adalah, faktor ekonomi, faktor tradisi atau kebiasaan, faktor Pendidikan dan faktor moral merupakan faktor yang dapat mempengaruhi terjadinya penyalahgunaan hak cipta orang lain untuk diambil keuntungan sendiri secara ilegal melalui platform digital yang menyediakan iklan berbayar

\section{DAFTAR PUSTAKA}

\section{Sumber Buku}

Rachmadi Usman, (2003). Hukum Hak atas

Kekayaan Intelektual: Perlindungan dan Dimensi Hukumnya di Indonesia, Bandung: PT Alumni.
Saifullah, (2007), Refleksi Sosiologi Hukum, Bandung, Refika Aditama.

Sudaryono, (2018) Metodologi Penelitian. Depok: Rajawali Pers.

Sugiyono, (2016) Metode Penelitian Kuantitatif, Kualitatif, $R \& D$. Bandung: Alfabeta. CV

Sri Kartini, (2020) Kesadaran Hukum. Semarang: Alprin Finishing and Bindery Shop.

\section{Jurnal dan Skripsi/Tesis}

Darmestha, Made Dwi. (2019). Perlindungan Hukum dalam Pengalihan Karya Musik yang Diunggah pada Sosial Media, Jurnal Analogi Hukum, Vol.1, No.2.

Desak Komang Lina Maharani, (2019). Perlindungan Hak Cipta Terhadap Pengguanaan Lagu Sebagai Suara Latar Video di Situs Youtube. Kertha Semaya : Journal Ilmu Hukum, Fakultas Hukum Universitas Udayana. Vol.7, No.10.

Jesi Andreanto dan Anak Agung Sri Utari, (2019). "Mekanisme Pembayaran Royalty Fee Berkaitan Dengan Cover Lagu Dalam Media Sosial Oleh" (2014): Kertha Semaya : Journal Ilmu Hukum, Fakultas Hukum Universitas Udayana. Vol.8, No.1. 
Nevey Varida Ariani, (2021). Penegakan

Hukum Pelanggaran dan Pemalsuan

Hak Cipta Dengan Munculnya Industri

Musik Digital, Jurnal Penelitian Hukum

De Jure, Vol.21, No.2.

Agus Suryono Komputro. (2016). Tinjauan Sosiologi Hukum Terhadap Efektifitas Undang-Undang No. 28 Tahun 2014 Tentang Hak Cipta Dalam Bidang Hak Cipta Lagu Di Kota Makassar. Skripsi tidak diterbitkan. Makassar: Universitas Hasanuddin Makasar.

Nanang Kuncoro (2021). Tinjauan UndangUndang Nomor 28 Tahun 2014 Tentang Hak Cipta Terhadap Cover Version Lagu Untuk Keperluan Komersil Tanpa Seizin Pencipta dan Perlindungan Hukum Hak Cipta Pencipta Lagu. Skripsi tidak diterbitkan. Surakarta: Universitas Muhammadiyah.

\section{Internet/Website}

https://www.dgip.go.id/pengenalan-hak-cipta https://apriyandis.wordpress.com/2011/12/31/m usik-digital/ https://id.wikipedia.org/wiki/Audio_digital

\section{Peraturan Perundang-Undangan}

Undang-Undang Nomor 28 tahun 2014 tentang Hak Cipta 